\title{
Green envelope as an architectural strategy for energy efficiency in a library building
}

\author{
Azlan Ariff Ali Ariff ${ }^{1}$, Sabarinah Sheikh Ahmad ${ }^{1,2 *}$, and Mohd Aljefri Hussin ${ }^{1}$ \\ ${ }^{1}$ Centre of Studies for Architecture, Faculty of Architecture, Planning \& Surveying, Universiti Teknologi MARA, UiTM Puncak \\ Alam Campus, Selangor, Malaysia \\ ${ }^{2}$ Tropical Building Performance Research Group, Faculty of Architecture, Planning \& Surveying, Universiti Teknologi MARA, \\ UiTM Puncak Alam Campus, Selangor, Malaysia
}

\begin{abstract}
In the context of Malaysian tropical climate, green envelope functions to provide satisfying indoor environment and achieve the best performance with minimal energy consumption. Buildings that rely on air-conditioning to improve thermal comfort could benefit from green envelope potentials. Hence, the objective of this paper is to explore the impacts of various types of green envelope towards reducing the energy consumption of a two-storey library building. The methodology approach is quantitative and data are collected through building simulation using Revit Building Information Modelling (BIM). Parameters studied are building orientation, wall insulation, envelope materials, and façade treatment. Results showed that different types of green envelope posed different impact on energy consumption of the library and double glazed windows contribute the most significant reduction of energy consumption. The study establishes the contribution of green envelope and advocates the use of building simulation as research methodology, as it helps to improve envelope design, and to predict the possible outcomes of design alternatives.
\end{abstract}

\section{Introduction}

Urban growth is inevitable, as developing countries face rapid population growth and increasing demands for energy. In 2016, the US Energy Information Administration predicted a $48 \%$ increase in world energy consumption between 2012 and 2040 [1].

Currently air-conditioning usage contributes to $40 \%$ of global building energy consumption. According to International Energy Agency, by 2050, Asia would call for $80 \%$ of air-conditioning demand.

In urban areas, passive design such as sun-shading devices, building orientation and thermal insulation are among of widely discussed topic in research. In lieu of passive design benefits, green building envelope should be considered as building skin acts as the first layer of defence against climatic threat [2].

The increase of energy demands calls for alternatives such as application of green approaches to reduce excessive energy consumption. This paper focuses on the study of green envelope approaches towards energy efficiency in a case study library building. The paper aims to investigate the applications of green envelope strategies that contribute to building energy efficiency.

\section{Literature Review}

\subsection{Green Envelope}

The primary function of building envelope is to provide protection from the outdoor environment where it serves a form of tangible barrier between the indoor space and outdoor environment [3].

Walls, floors, roofs, fenestrations, and doors make up the components of building envelope. Weather proofing, heat resistance, air barrier, thermal insulation, light and acoustic properties are the fundamentals of building envelope [4] and can be appraised as successful if these criteria are fulfilled [5].

In addition to that, building orientation, shape, envelope system, passive cooling mechanisms, shading, and glazing are the suitable parameters for the analysis of building envelope [6] depending on the climatic conditions.

Kibert [7] mentioned that energy strategy for green building is to design a building that emulates the concept of net zero energy (NZE) with much attention on passive design to maximize daylighting and natural cooling. It is of great importance for the comfort of the user and the energy conservation that designers must ensure good conditions of thermal, visual and acoustic comfort in buildings with minimal energy consumption.

In summary, green envelope can be defined operationally as building skin that responds to the surrounding context with minimal impact whilst keeping the occupants in satisfactory human comfort at a cost of efficient energy consumption.

\footnotetext{
* Corresponding author: sabrin63@gmail.com
} 


\subsubsection{Envelope for Tropical Climate}

A well-designed envelope responds to the local climate. Therefore, the main strategy of building envelope in context of hot and humid tropical climate is to keep off the heat from sun as well as allow natural ventilation, and building envelope ideally should admit breeze while keeping out the rain [8].

The effectiveness of building envelopes can be measured by the ability to protect the internal environment from the surrounding environment, retain good quality indoor air, durability, influx of natural light, and energy efficiency [9].

\subsubsection{Walls}

Understanding and optimising the thermal transmittance through the walls is crucial in designing high performance building. Passive design strategies create more potential of energy saving and efficiency by reducing the amount of energy required by active system using thermal mass and insulation.

\subsubsection{Insulation}

Thermal insulation is a building material that prevents or reduces heat flow through the building envelope from entering the building. Insulation is designed primarily to prevent heat transmittance from solar radiation [10]. Most green building design incorporates insulation because it allows the building spaces to preserve the existing heat, while avoiding excess heat gain from outside.

\subsubsection{Windows}

Windows allow penetration of natural daylight deeper into buildings and while providing desired ventilation. Heat transmittance through windows and skylights demands for design treatment to improve thermal comfort due to the key factors that fenestration affects human thermal comfort [11].

Special design treatments such as window glazing are made possible thanks to the wide selections of building components with each displaying different performance in achieving optimum building energy efficiency.

\subsubsection{Roof}

Liu [12] in his book mentioned that green roof was more effective in controlling heat gain where during observation period, the garden roof reduced heat gain by $95 \%$ and heat loss by $26 \%$, with an overall reduction in heat flow of $47 \%$ compared to the conventional roof. As Malaysia is in the tropical hot-humid region, energy savings derived from the use of extensive green roof is most likely to be substantial by elimination of energy consumption due to air-conditioning cooling load which typically makes up the biggest fraction of energy [13].

\subsubsection{Building Orientation}

Orientation is the compass direction of the building. Along with massing, orientation can be a significant step towards a building with passive thermal and visual comfort [14]. Successful orientation gives advantages to building mass by reduction of heat/cooling loads and maximises free energy from daylight and natural ventilation.

\subsubsection{Sun shading and Redirection of Sunlight}

Sun shading is a part of crucial strategies to achieve both visual and thermal comfort [15]. Overhangs, louvers and vertical fins are examples of sun-shading devices. Meanwhile, devices that redirect sunlight are light shelves and baffles.

Sun-shading devices can reduce visual glare and heat transmittance of direct sun through windows, while still allowing generous visible light and views to penetrate into the building. These applications are able to keep direct sunlight away from the building envelope to help in cooling loads reduction [16].

\subsection{Energy Efficiency}

Energy efficient building design is one of the approaches in reducing energy consumption. The key objective of energy efficient building is to design a building that offers similar or better performance in comparison to other similar building at lower energy consumption [17]. Key factors that influence building energy consumptions are site planning and micro climate, building scale and form, construction detailing, building orientation, thermal capacity, thermal resistance, and window systems [18].

When green envelope is incorporated into a building, the energy consumption can be reduced passively. Therefore, the potential of green envelope should be taken into consideration when designing energy efficient building.

\section{Research Methodology}

The methodology approach is quantitative and data are collected through building simulation using Autodesk Revit BIM software. Unlike comparative study, the collected data generated by the simulations is a primary data and the readings collected through the simulation are quite accurate [19]. This paper presents building simulation as an appropriate research methodology to measure the effectiveness of building envelopes and cope with complexity of the study.

\subsection{Building Simulation using Autodesk Revit}

Revit is one of many BIM simulation software used as a tool to evaluate and notify decisions collectively during the design process, from early design stage [20] where the project team can analyse design solution alternatives 
and make informed decisions based on the data obtained [21].

A series of building simulation is conducted using Revit with settings emulated to match the real time environment. The impact of green envelope on building energy efficiency is studied based on annual building performance instead of monthly where the differences between the variables are less significant.

\subsubsection{Parameters of Green Envelope}

The experiments are predicted to show the behaviour of the each variance would validate the effect of respective green envelope on the energy consumption, and create better understanding of the envelope behaviour and efficiency. The lesser the amount of energy consumption indicates the more efficient envelope.

Five green envelope variances are selected and modelled after the base case (control) is determined, namely wall insulation, double glazed window, green roof, building orientation (north-south orientation) and application of sun-shading device as shown in Table 1.

Table 1. Variances of green envelope (Source: Author)
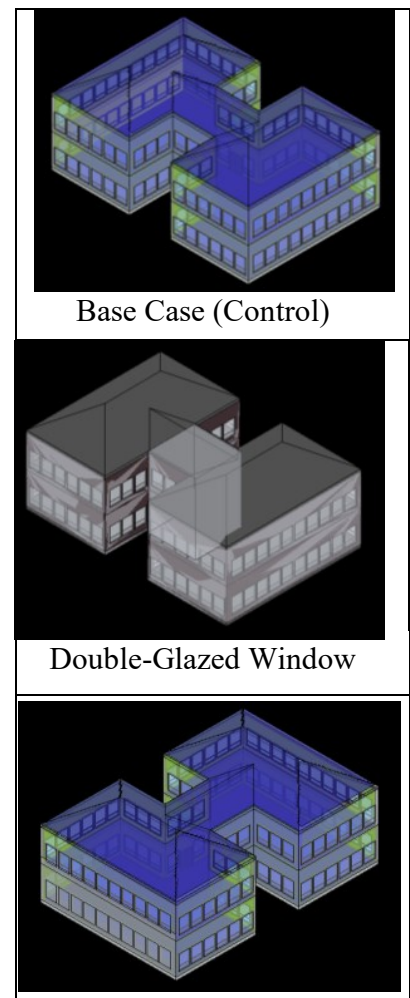

Orientation (north-south)

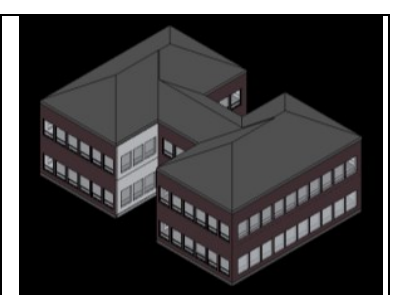

Insulated wall

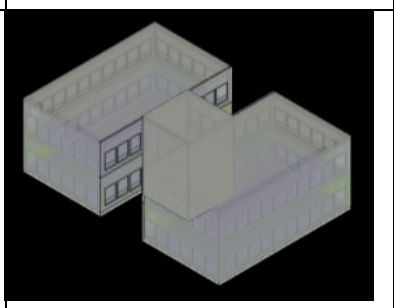

Green Roof

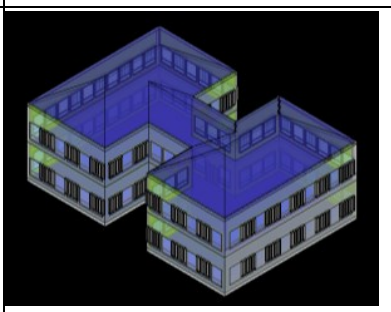

Sun-shading Device
First, a base case or a control 3D model of a library building is generated with building envelope consists of generic wall, unglazed windows, generic roof construction and concrete flooring as control.

For this building simulation, the control building is set facing east-west and the environment setting used is to emulate Kajang location for 12 months interval (JanDec) and kept constant as shown in Table 1 top left box.
Building materials chosen from the Revit library are kept constant for all simulations. Next, energy efficiency building simulation is carried out using the control model as base case study. The result is recorded and generated by Autodesk. Building simulation is then repeated using different models with respective green envelope applications as shown in Table 2.

Table 2. Fixed environment settings of Revit building simulation (Source: Author)

\begin{tabular}{ll}
\hline Location & $\begin{array}{l}\text { Jalan Bukit, Taman Kajang Jaya, } \\
\text { 43000 Kajang, Selangor, Malaysia }\end{array}$ \\
\hline Weather Station & $1446802(\mathrm{GPS}$ Location - M'sia) \\
\hline Coordinate & $2.9935^{\circ} \mathrm{N}, 101.7874^{\circ} \mathrm{E}$ \\
\hline Floor Area & $827 \mathrm{~m}^{2}$ \\
\hline Exterior Wall Area & $571 \mathrm{~m}^{2}$ \\
\hline Average Lighting Power & $12.70 \mathrm{~W} / \mathrm{m}^{2}$ \\
\hline Building Occupancy & 83 people \\
\hline
\end{tabular}

Table 3. Variable setting of Revit simulation (Source: Author)

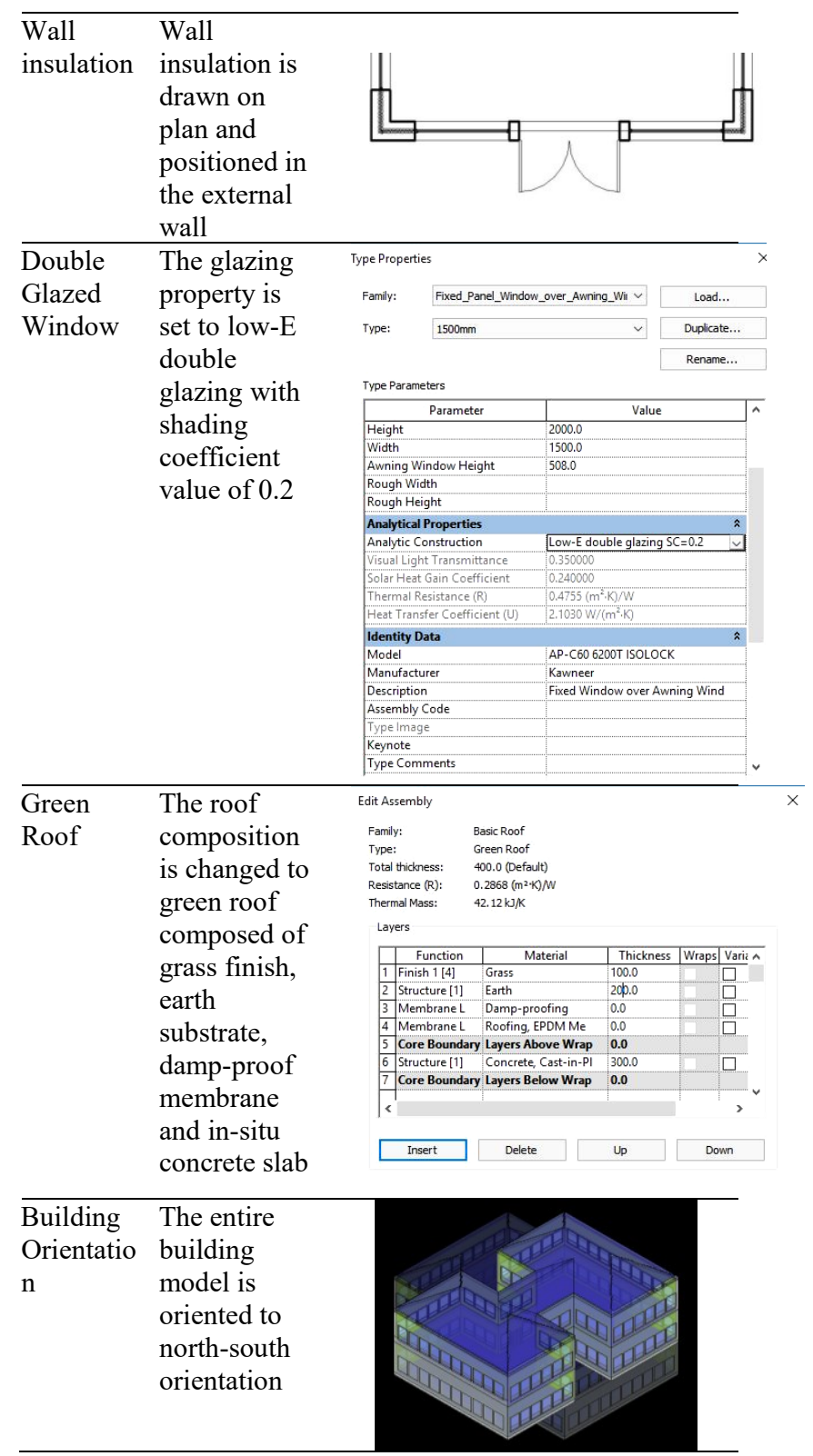




$\begin{array}{ll}\begin{array}{l}\text { Sun- } \\ \text { shading }\end{array} & \begin{array}{l}\text { Addition of } \\ \text { sun-shading } \\ \text { Device } \\ \text { and placed on } \\ \text { window }\end{array}\end{array}$

Finally, results and data obtained based on all the simulations are translated into bar charts using an Excel sheet. Chart and figures are analysed, discussed and concluded.

\section{Results and Findings}

Energy analysis reports generated from the building simulation include many forms of energy performance. The following aspects of energy are selected, namely building performance, annual energy use/cost, annual electricity usage, energy use intensity (EUI), energy efficiency of green envelopes, and annual energy consumption. These results are discussed in relation to energy consumption and energy efficiency.

\subsection{Annual Energy Use}

Figure 1 shows the total annual energy use of different types of green envelope applied on the building. Green roof as green envelope reduced the energy consumption from $207,693 \mathrm{kWh}$ to $77,738 \mathrm{kWh}$, a tremendous reduction of $62.6 \%$ from the control. Next, doubleglazed windows are applied, which recorded more than double the energy consumption of green roof at 163,368 $\mathrm{kWh}$.

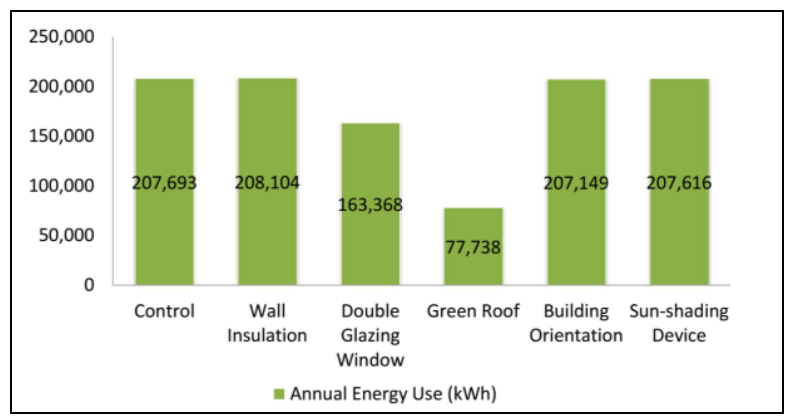

Figure 1: Annual Energy Use of Green Envelope (Source: Author)

\subsection{Electricity Usage}

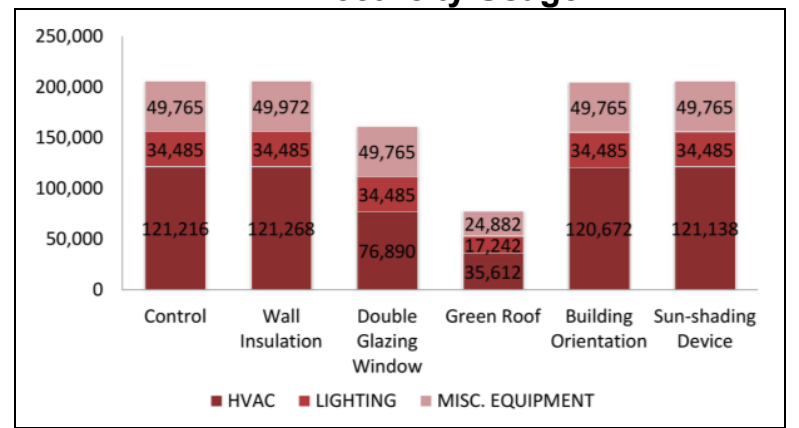

Figure 2: Electricity consumption breakdown of Green Envelope (Source: Author)
Figure 2 shows total annual electrical energy use breakdown of different types of green envelope applied on the building. Generally, each green envelope displays similar energy consumption in lighting and miscellaneous equipment, except green roof that shows reduction of energy consumption by $70.6 \%$ to 35,612 $\mathrm{kWh}$, with total energy consumption lesser than HVAC electrical consumption recorded by the control building.

\subsection{Energy Use Intensity}

Figure 3 shows the results of simulations for annual electricity energy use intensity, where the most effective green envelope strategy is the green roof variant with $25.1 \%$ of reduction from the control with energy saving of $63 \mathrm{kWh} / \mathrm{m}^{2} /$ year annually. The second most efficient green envelope is the double glazed window, showing a competitive rate against green roof with difference of 10 $\mathrm{kWh} / \mathrm{m}^{2} /$ year.

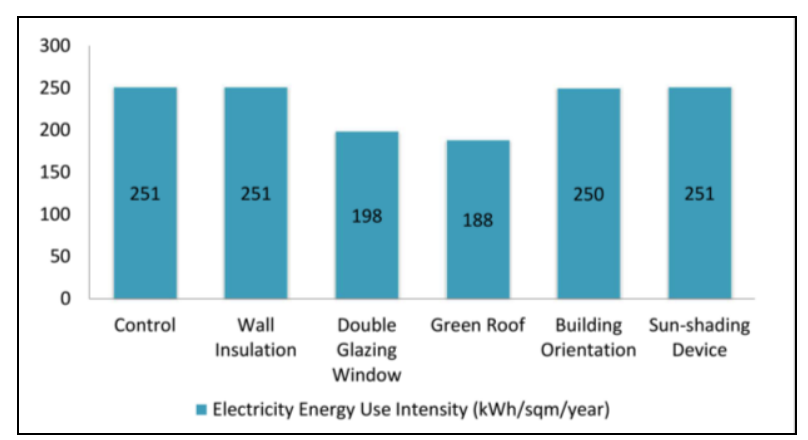

Figure 3: Energy Use Intensity of Green Envelopes (Source: Author)

\subsection{Energy Efficiency of Green Envelopes}

Figure 4 shows the overall energy efficiency of each variation of green envelope. The efficiency result is generated through building simulation by considering all the factors of energy consumption measurements such as total energy use, total electricity consumption and energy use intensity.

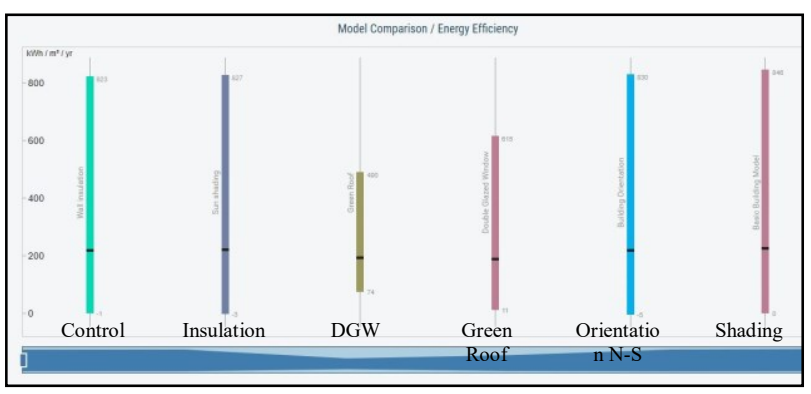

Figure 4: Energy Efficiency of Green Envelopes (Source: Author) 
Table 4. Overall Energy Consumption of Green Envelope (kWh/m2/year) (Source: Author)

\begin{tabular}{|l|c|c|c|c|c|c|}
\hline Model & $\begin{array}{l}\text { Wall } \\
\text { Insulation }\end{array}$ & $\begin{array}{l}\text { Sun } \\
\text { Shading }\end{array}$ & $\begin{array}{l}\text { Green } \\
\text { Roof }\end{array}$ & $\begin{array}{l}\text { Double } \\
\text { Glazed } \\
\text { Window }\end{array}$ & $\begin{array}{l}\text { Building } \\
\text { Orientation }\end{array}$ & $\begin{array}{l}\text { Basic } \\
\text { Control } \\
\text { Model }\end{array}$ \\
\hline Maximum & 823 & 827 & 490 & 615 & 830 & 846 \\
\hline Mean & $\mathbf{2 1 8}$ & $\mathbf{2 2 0}$ & $\mathbf{1 9 3}$ & $\mathbf{1 8 8}$ & $\mathbf{2 1 8}$ & $\mathbf{2 2 6}$ \\
\hline Min & -1 & -3 & 74 & 11 & -5 & 0 \\
\hline
\end{tabular}

Table 4 shows the maximum, mean and minimum use of energy consumption rate. As an overview, each green envelope strategy records a reduction from the base case control building. This verifies the green envelope approach as a strategy for energy consumption reduction and energy efficiency.

The best way to determine the best energy efficient green envelope is by comparing the mean of energy consumption of each envelope, due to huge range maximum and minimum value difference. While green roof may prove consistent and impactful reduction for each energy valuation, it is outperformed by double glazed window when all of the measurements are taken into account, clearly indicated by its lowest mean value. Thus, it can be inferred that double glazed window has the highest energy efficiency compared with other green envelopes.

\section{Conclusion}

The objective of the research is to investigate the applications of green envelope strategies that contribute to building energy efficiency based on computer simulations. The findings showed that double glazed windows contributed the most for energy efficient building based on the significant reduction of energy consumption.

This research has concluded that different types of green envelope contribute positively by optimising the energy consumption of the building thus improving the building energy efficiency.

The application of building simulation as research methodology responded well in the understanding of how application of green envelope affects the energy consumption of a building. The results obtained are easily assessed, clear and answers the objective of this research. In summary, wider use of simulation as research methodology is highly recommended as it may strengthen the reliability and soundness of theoretical statements.

Further research could study the size or thickness of the green envelopes as well as the material used as different types of material display different thermal transmittance and affect the overall building energy consumption when used as envelope building material. Through the advancement of BIM technology, different alternatives of design strategy can be tested and predicted.

Funding towards the presentation and publication of this paper is made possible by UiTM Bestari research grant scheme 600-IRMI/MyRA 5/3/BESTARI (035/2017).

\section{References}

1. A. Sieminski, International Energy Forum October 31, 2016. EIA's International Energy Outlook 2016 (2016)

2. A. E. Del Grosso \& P. Basso, S. M. and Struct. 19(12), 124011 (2010)

3. S. Mirrahimi,, M. F. Mohamed, L. C. Haw, N. L. N. Ibrahim, W. F. M. Yusoff, A. Aflaki, Renewable and S. E. Reviews 53, 1508-1519 (2016)

4. A. S. Nasser, Envelope design for thermal comfort and reduced energy consumption in residential buildings ( $\mathrm{PhD}$ diss., King Fahd University of Petroleum and Minerals, 2006)

5. A. S. Mohammad, Bldg. and Env. 40, 353-366. (2005)

6. E. J. Gago, J. Roldan, R. Pacheco-Torres, J. Ordóñez, Renewable and S. E. Reviews 25, 749-758 (2013)

7. C. J. Kibert, Sustainable construction: green building design and delivery (J. W. \& Sons, 2016).

8. N. A. Al-Tamimi, S. F. S. Fadzil, Procedia Engineering 21, 273-282 (2011)

9. K. Liu, B. Baskaran, Proceedings for the First North American Green Roof Infrastructure Conference, Awards and Trade Show, Thermal performance of green roofs through field evaluation, 29-30 (2003)

10. F. Kreith, R. M. Manglik, M. S. Bohn, Principles of heat transfer (Cengage learning, 2012).

11. P. R. Lyons, D. Arasteh, C. Huizenga, TransactionsAmerican Soc. of H.R. and A.C. Engrs 106(1), 594604 (2000)

12. K. K. Liu, A. Baskaran, Inst. for Res. in Construction, National Research Council of Canada, Using garden roof systems to achieve sustainable building envelopes (2005)

13. H. F. Castleton, V. Stovin, S. B. Beck, \& J. B. Davison, Energy and buildings, Green roofs; building energy savings and the potential for retrofit. 42(10), 1582-1591 (2010)

14. A. H. Sherif, H. M. Sabry, M. I. Gadelhak, Solar Energy 86(11), 3353-3363 (2012)

15. C. E. Ochoa, M. B. Aries, E. J. van Loenen, J. L. Hensen, Applied Energy 95, 238-245 (2012)

16. A. Tzempelikos, A. K. Athienitis, P. Karava, Solar Energy 81(9), 1088-1103 (2007)

17. A. J. Marszal, P. Heiselberg, J. S. Bourrelle, E. Musall, K. Voss, I. Sartori, A. Napolitano, Energy \& buildings 43(4), 971-979 (2011)

18. C. S. Aun, CPD Seminar, Kuala Lumpur 2009, Green Building Index-MS1525: Applying MS1525: 2007 Code for Practice on energy efficiency and use of renewable energy for non-residential buildings (2009)

19. A. Aksamija, Perkins+Will Research Journal 5(1), 19-37 (2013).

20. E. Krygiel, B. Nies, Green BIM: successful sustainable design with building information modeling (J. W. \& Sons, 2008).

21. K. Kensek, D. Noble, Building information modeling: BIM in current and future practice. (J. W. \& Sons, 2014). 